\title{
RELIGIJNE SPOSOBY RADZENIA SOBIE A STRES I WYPALENIE ZAWODOWE U NAUCZYCIELI RELIGII
}

\begin{abstract}
STRESZCZENIE
Zawód nauczyciela jest w dużym stopniu narażony na stres i wypalenie. Według modelu wymagania-zasoby narażeni na wypalenie są szczególnie ci pracownicy, którzy dysponując niskimi zasobami, znajdują się w sytuacji wysokich wymagań. Przedmiotem badań był związek między trzema zmiennymi: religijnymi sposobami radzenia sobie (Brief RCOPE), traktowanymi jako zasoby osobowe, stresem (SSN), wyrażającym wymagania w pracy, i wypaleniem zawodowym (MBI). Badaniami objęto 419 nauczycieli religii. Stwierdzono, że negatywne strategie zaradcze korelują dodatnio z każdym wymiarem wypalenia, pozytywne strategie zaradcze natomiast korelują z wypaleniem ujemnie. Ponadto pozytywne religijne radzenie sobie moderuje relację między stresem a wypaleniem zawodowym w taki sposób, że dodatnia relacja między stresem a wypaleniem jest słabsza, przy większym nasileniu pozytywnych strategii zaradczych.
\end{abstract}

Słowa kluczowe: stres, wypalenie zawodowe, religijne sposoby radzenia sobie, nauczyciele religii

\section{RELIGIOUS COPING, STRESS AND BURNOUT AT RELIGIOUS EDUCATION TEACHERS}

\begin{abstract}
The teaching profession is exposed to stress and burnout. According to the job demands-resources model, employees with few resources and high demands are exposed to burnout especially. A subject of the study was the relationship among three variables: religious coping (Brief RCOPE) given as particular personal resources, stress (SSN) considered as job demands, and burnout (MBI). This study examined $419 \mathrm{RE}$ teachers. It was found that the negative religious coping positively correlated with every dimension of burnout, whereas positive religious coping negatively correlated with burnout. Moreover, positive religious coping moderated the relation between stress and burnout. More specifically, the relation was weaker for teachers with high positive religious coping.
\end{abstract}

Keywords: stress, burnout, religious coping, religious education teachers

\footnotetext{
$1 \quad$ Adres do korespondencji: piotradam@tlen.pl.
} 
Zjawisko wypalenia zawodowego stanowi przedmiot zainteresowania psychologów od przeszło czterech dekad. Spośród wielu określeń wypalenia wciąż dużym uznaniem cieszy się ujęcie zaproponowane przez Maslach (1982), pionierkę badań w tej dziedzinie. Opisuje ona to zjawisko jako konstrukt składający się $\mathrm{z}$ trzech wymiarów: emocjonalnego wyczerpania, depersonalizacji oraz obniżonego poczucia osiągnięć osobistych.

Wyczerpanie emocjonalne (emotional exhaustion) wyraża się ogólnym zmęczeniem, brakiem energii i zapału do pracy. Ludzie wyczerpani emocjonalnie czują, że muszą wkładać coraz więcej wysiłku w wykonywane przez siebie zajęcia, na co mają coraz mniej sił. Trudno im także odpocząć i zregenerować swoje zasoby. Wyczerpanie jest uważane za pierwszą reakcję na przedłużający się stres. Depersonalizacja (depersonalization) polega na dystansowaniu się wobec innych osób, utracie wrażliwości na przeżywane przez nich problemy, a nawet na odnoszeniu się do innych ludzi z pogardą. Postawa taka stanowi poniekąd sposób radzenia sobie z emocjonalnym obciążeniem narastającym w relacjach interpersonalnych w pracy. Obniżone poczucie osiągnięć osobistych (reduced personal accomplishment) oznacza spadek poczucia własnej kompetencji i sukcesów zawodowych. Im bardziej pracownik czuje, że nie jest skuteczny, tym mocniej narasta w nim poczucie braku własnej wartości oraz sensu wykonywanej przez niego pracy (Maslach, 1998, 2010; Maslach, Leiter, 2011). Takie ujęcie wypalenia dobrze oddaje specyfikę pracy nauczyciela, która należy do grupy zawodów wymagających dużego zaangażowania w relacje interpersonalne o charakterze asymetrycznym (dawca-biorca).

Współcześnie problematykę wypalenia próbuje się postrzegać w szerszej perspektywie aktywności zawodowej, traktując to zjawisko jako erozję zaangażowania w pracę (Maslach, Leiter, 2011). Takie podejście do wypalenia znalazło swoje odzwierciedlenie w modelu wymagania-zasoby ( job demandsresources - JD-R) przedstawionym przez Demerouti, Bakkera, Nachreinera i Schaufeliego (2001). Jest to jedna z nowszych propozycji całościowego ujęcia czynników wpływających na funkcjonowanie zawodowe pracowników. Twórcy tej koncepcji wyróżnili wymagania panujące w środowisku pracy (job demands) oraz zasoby zawodowe (job resources). Pierwsza kategoria ujmuje fizyczne, społeczne lub organizacyjne aspekty pracy, wymagające od pracownika zaangażowania jego sił fizycznych i umysłowych oraz związane z określonymi kosztami fizjologicznymi bądź psychologicznymi. Druga kategoria czynników grupuje te elementy związane z pracą, które pozwalają zatrudnionym zachować dobre funkcjonowanie, nawet przy wysokich wymaganiach. Zalicza się do nich fizyczne, społeczne lub organizacyjne aspekty pracy, które prócz tego, że pomagają osiągać cele zawodowe i zmniejszać związane z wymaganiami koszty, stymulują zdobywanie i rozwój własnych kompetencji (Demerouti i in., 2001; Bakker, Demerouti, 2007; Demerouti, Bakker, 2011). 
W prezentowanym modelu JD-R autorzy wychodzą z założenia, że wypalenie zawodowe następuje w wyniku dwóch procesów oddziałujących na pracownika. Pierwszy z nich, zwany energetycznym, jest uruchamiany jako efekt zbyt dużych wymagań w środowisku pracy. Jego skutkiem jest narastający stres, a następnie przeciążenie osoby i jej wyczerpanie. Drugi proces, nazywany motywacyjnym, jest związany z niedostateczną ilością zasobów zawodowych, co przy wysokich wymaganiach stawianych pracownikowi prowadzi do spadku jego zaangażowania i do pogorszenia efektywności pracy (Demerouti i in., 2001).

W rezultacie przeprowadzonych badań wykazano, że zasoby zawodowe odgrywają rolę bufora między wymaganiami a wypaleniem zawodowym (Bakker, Demerouti, 2007). Bakker, Demerouti i Euwema (2005) odkryli, że nadmiar pracy, fizyczne i emocjonalne obciążenie oraz prace domowe wykonywane przez pracowników instytutu szkolnictwa wyższego nie skutkowały wysokim poziomem wypalenia, gdy doświadczali oni autonomii, uzyskiwali informacje zwrotne, odczuwali wsparcie społeczne lub mieli bardzo dobre relacje z przełożonym. Podobnych dowodów dostarczyły badania prowadzone przez Xanthopoulou, Bakkera, Dollard i in. (2007) wśród osób zatrudnionych w zakładach opieki domowej. Sytuacja, w której wymagania były wysokie, a zasoby pozostawały ograniczone, skutkowała najwyższym poziomem wypalenia zawodowego, gdy tymczasem obecność zasobów znacząco je redukowała. Istotną rolę zasobów zawodowych potwierdziły wyniki badań zrealizowanych przez Bakkera, Hakanena i Demerouti (2007) wśród nauczycieli zatrudnionych w podstawowych, średnich i zawodowych szkołach w Finlandii. Gdy niewłaściwe zachowania uczniów znacząco się nasilały, ich wpływ na zaangażowanie nauczycieli zależał w szczególnej mierze od dostępności zasobów zawodowych, takich jak: wsparcie przełożonych, otwarcie na nowe pomysły, uznanie dla pracy nauczyciela, atmosfera panująca $\mathrm{w}$ miejscu pracy.

W badaniach bazujących na modelu JD-R podejmowano także próby rozszerzenia zasobów zawodowych o takie dyspozycje pracownika jak: związane z przynależnością do zakładu pracy poczucie własnej wartości, przekonanie o własnej skuteczności czy optymizm (Xanthopoulou, Bakker, Demerouti i in., 2007). Demerouti i Bakker (2011) uważają, że uwzględniane w badaniach nad stresem takie zasoby jednostki jak: umiejętność radzenia sobie ze stresem, zdolność pozytywnej interpretacji trudnych sytuacji, posiadanie określonych cech osobowości oraz silne poczucie własnej skuteczności, nadzieja, optymizm czy prężność osobowa stanowią istotne czynniki mające wpływ na funkcjonowanie zawodowe. Zdaniem autorów szczególnie narażeni na wypalenie są ci pracownicy, którzy posiadając niskie zasoby osobowe, znajdują się w sytuacji wysokich wymagań i małej dostępności zasobów w swoim miejscu pracy.

Nawiązując do procesów opisanych w modelu JD-R, w prezentowanych badaniach przyjęto, że kłopoty z utrzymaniem porządku w klasie oraz niewłaściwe zachowania wychowanków stanowią w pracy nauczycieli ten element wymagań, 
który jest istotnym czynnikiem potęgującym ryzyko wypalenia w tym zawodzie (Burke, Greenglass, Schwarzer, 1996; Hreciński, 2016; Tucholska, 2009). Religijne sposoby radzenia sobie ze stresem zaliczono zaś do zasobów pracownika, które stanowią bufor między stresem związanym z tymi wymaganiami a wypaleniem zawodowym. Zdaniem Pargamenta (1997) w trudnych sytuacjach ludzie wierzący odwołują się do religii na różne sposoby: modlą się sami lub z innymi, rozmawiają z duchownymi, czytają Biblię itd. Przyjmuje się, że człowiek, odwołując się w stresie do religii, może: 1) pozostać bierny, oczekując aktywności ze strony Boga, 2) prosić Boga o wsparcie w samodzielnie podejmowanych działaniach lub 3) zajmować postawę współpracy z Bogiem w rozwiązywaniu zaistniałej sytuacji (Jarosz, 2011). Niektóre z tych aktywności włączają się w proces nadawania religijnego znaczenia doświadczanym trudnościom, inne stanowią zachowania odwracające uwagę od stresorów, łagodzące emocje lub motywujące do rozwiązania problemu. Odwołując się do opracowanej przez Lazarusa i Folkman (1984, za: Heszen-Niejodek, 2000) koncepcji stresu i radzenia sobie, można stwierdzić, że religijne strategie zaradcze stają się częścią poznawczych $\mathrm{i}$ behawioralnych działań podejmowanych $\mathrm{w}$ celu usunięcia przyczyn stresu lub minimalizacji jego skutków.

Wyniki badań przeprowadzonych wśród nauczycieli wykazały, że praktykowana przez nich modlitwa stanowiła pomoc w radzeniu sobie ze stresem. Osoby poświęcające jej więcej czasu częściej postrzegały swoją pracę jako powołanie i mimo napotykanych trudności chciały pozostać w zawodzie (LaBarbera, Hetzel, 2016). Osobista modlitwa i uczęszczanie do kościoła praktykowane przez nauczycieli szkół katolickich ujawniły natomiast pozytywne związki z poczuciem osiągnięć osobistych i satysfakcją zawodową, negatywnie zaś korelowały $\mathrm{z}$ wyczerpaniem emocjonalnym, chęcią zmiany zawodu oraz kłopotami zdrowotnymi (Chirico, 2017). W badaniach przeprowadzonych wśród nauczycieli religii pracujących w polskich szkołach radzenie sobie ze stresem przez stosowanie praktyk religijnych jako źródła wsparcia emocjonalnego oraz wskazówki do pozy tywnego przewartościowania i rozwoju negatywnie korelowało z każdym $\mathrm{z}$ wymiarów wypalenia, największe zaś związki ujawniło z obniżonym poczuciem osiągnięć w pracy (Hreciński, 2016).

W badaniach nad wypaleniem i religijnymi sposobami radzenia sobie najczęściej nie bierze się pod uwagę, że nie każde odwołanie do religii pozwala na korzystne rozwiązanie trudnej sytuacji. Tymczasem wśród religijnych sposobów radzenia sobie można wyróżnić dwie zasadnicze kategorie. Określa się je mianem strategii pozytywnych (positive religious coping; PRC) albo negatywnych (negative religious coping; NRC), adekwatnie do tego, czy ich stosowanie okazuje się zazwyczaj korzystne czy też niekorzystne w rozwiązywaniu problemów (Pargament, Feuille, Burdzy, 2011). Przykładem badań dotyczących problematyki wypalenia i radzenia sobie, mających na względzie te dwa zasadnicze sposoby korzystania z religii, są badania podłużne nad wypaleniem uczniów 
szkół średnich w Korei (Noh, Chang, Jang, Lee, Lee, 2016): PRC miały ujemny, a NRC - dodatni związek z poziomem wypalenia, mierzonym po czterech miesiącach nauki szkolnej.

Religijne sposoby radzenia sobie są oczywiście bardziej skuteczne, gdy religijność danej osoby zajmuje centralną pozycję wśród jej konstruktów osobistych (Jarosz, 2011). Potwierdziły to m.in. wyniki wspomnianych już badań nad wypaleniem uczniów w szkołach średnich (Noh i in., 2016).

Prezentowane w tym artykule badania miały na celu odpowiedź na następujące pytanie: Jaka jest współzależność między religijnymi sposobami radzenia sobie a odczuwanym stresem i wypaleniem zawodowym?

Zgodnie z zaproponowaną przez Pargamenta (1997) teorią religijnego radzenia sobie osoby religijne mają możliwość odwoływania się do swoich zasobów duchowych, aby z ich pomocą poradzić sobie z różnymi problemami. Istnieje wiele różnorodnych, opartych na religii metod radzenia sobie ze stresem. Ze względu na ich funkcję adaptacyjną wyróżniono pozytywny i negatywny wzór religijnego radzenia sobie. PRC obejmują: religijne przewartościowanie doświadczanych trudności, poszukiwanie wsparcia duchowego od Boga, poszukiwanie wsparcia duchowego od członków wspólnoty religijnej. Zachowania te są uznawane za efektywne metody radzenia sobie, chroniące jednostkę przed niekorzystnymi skutkami stresu (Bartczuk, Jarosz, 2006). Ponieważ jednym ze skutków przedłużającego się stresu w pracy jest wypalenie zawodowe (Maslach, 2010), sformułowano następującą hipotezę szczegółową:

H1: Pozytywne religijne radzenie sobie koreluje ujemnie ze stresem i wypaleniem zawodowym.

Drugi wzór religijnych strategii zaradczych obejmuje NRC. Należą do nich: przewartościowanie trudnych sytuacji jako kary Bożej, przejawu braku mocy Boga lub efektu działania demona, wyrażanie niezadowolenia z Boga i wspólnoty religijnej. Zachowania te są uważane za nieskuteczne sposoby radzenia sobie ze stresem, dlatego też wiążą się z jego różnymi następstwami (Bartczuk, Jarosz, 2006). Biorąc to pod uwagę, w odniesieniu do kontekstu badań własnych sformułowano następującą hipotezę szczegółową:

$\mathrm{H}$ 2: Negatywne religijne radzenie sobie koreluje dodatnio ze stresem i wypaleniem zawodowym.

W niniejszych badaniach wzajemne relacje między stresem w pracy nauczycieli religii, religijnymi strategiami zaradczymi oraz wypaleniem zawodowym zostały określone w modelu teoretycznym JD-R (Bakker, Demerouti, 2007; Xanthopoulou, Bakker, Demerouti i in., 2007). Zgodnie z jego założeniami, PRC, które są tutaj traktowane jako jeden z zasobów osobowych nauczycieli, mają odgrywać rolę bufora między wywołującymi stres obciążeniami a wypaleniem zawodowym. Bazując na współzależnościach postulowanych w modelu JD-R, sformułowano następującą hipotezę szczegółową: 
H3: Pozytywne religijne radzenie sobie moderuje relację między stresem a wypaleniem zawodowym w taki sposób, że dodatnia relacja między stresem a wypaleniem jest słabsza, przy większym nasileniu pozytywnych strategii zaradczych.

\section{MetodA}

\section{Osoby badane i sposób przeprowadzenia badań}

Badania były prowadzone wśród aktywnych zawodowo nauczycieli religii. Spełniono tym samym postulat wyrażający sensowność badania metod religijnego radzenia sobie jedynie wśród osób religijnych (Jarosz, 2011). Ponieważ większość katechetów pracujących w polskim systemie oświaty przynależy do Kościoła rzymskokatolickiego, badaniami objęto właśnie tę grupę osób. Do analiz włączono dane pochodzących od 419 respondentów: 281 kobiet i 133 mężczyzn (pięć osób nie podało płci). Wśród katechetek większość stanowiły osoby świeckie (80\%), w grupie mężczyzn zaś przeważały osoby duchowne (65\%). Dysproporcja liczby kobiet w stosunku do mężczyzn w gronie katechetów świeckich odzwierciedla zjawisko feminizacji zawodu nauczyciela. Średnia wieku w badanej grupie wynosiła 40,8 roku $(S D=8,17)$, przy czym mężczyźni $(M=$ $36,5 ; S D=8,09)$ byli statystycznie blisko sześć lat młodsi od kobiet $(M=42,7$; $S D=7,42$ ). Wiąże się to $\mathrm{z}$ podejmowaniem przez duchownych pracy w szkole zazwyczaj w początkowych latach ich działalności duszpasterskiej.

Osoby badane były zatrudnione przede wszystkich w szkołach znajdujących się na terenie województwa lubelskiego (60\%), a w dalszej kolejności: podlaskiego (8\%), śląskiego (8\%) i dolnośląskiego (5\%). Żaden z respondentów nie pochodził z województwa warmińsko-mazurskiego ani opolskiego. Przedstawicieli z pozostałych regionów Polski było mniej niż 5\% dla poszczególnych województw.

Biorąc pod uwagę etap nauczania: $26,7 \%$ katechetów pracowało tylko w szkołach podstawowych, $23,8 \%$ tylko w szkołach ponadgimnazjalnych, $11,9 \%$ tylko w gimnazjach, $0,7 \%$ tylko w przedszkolach. Pozostali nauczyciele wykonywali swoją pracę w szkołach różnego typu.

Prośba o udział w badaniach była kierowana przy okazji organizowanych dla katechetów szkoleń, konferencji naukowych i działań duszpasterskich oraz za pośrednictwem wydziałów katechetycznych. Badania miały charakter anonimowy i dobrowolny.

\section{Narzędzia badawcze}

Kwestionariusz wypalenia zawodowego (Maslach Burnout Inventory; MBI). Narzędzie to w wersji oryginalnej zostało opracowane przez Maslach i Jackson (1981). Druga edycja tego kwestionariusza zawierała także wariant przeznaczony do badań prowadzonych wśród nauczycieli (Maslach, Schaufeli, Leiter, 2001). $\mathrm{W}$ niniejszych analizach wykorzystano polską wersję kwestionariusza, opracowaną 
przez Tucholską (2009). Podobnie jak wersja oryginalna, składa się on z 22 pozycji testowych i pozwala na pomiar poziomu wypalenia w jego trzech dymensjach:

1. Emocjonalne wyczerpanie (dziewięć itemów; $a$ Cronbacha $=0,86$ ) określa poczucie emocjonalnego i ogólnego zmęczenia pracownika, jego energię do pracy oraz zdolności organizmu do regeneracji utraconych sił. Przykładowa pozycja należąca do tego wymiaru brzmi: Pod koniec dnia pracy czuję się bardzo wyczerpany;

2. Depersonalizacja (pięć itemów; a Cronbacha $=0,69$ ) ocenia apersonalną postawę nauczyciela wobec innych, przede wszystkich wobec uczniów. Przykładowa pozycja tego wymiaru brzmi: Czuję, że traktuję uczniów raczej w sposób bezosobowy i przedmiotowy;

3. Brak poczucia osiągnięć (osiem itemów; $\alpha$ Cronbacha $=0,76$ ) pozwala ocenić odczuwaną przez nauczyciela zdolność do rozumienia podopiecznych, wartość swojej pracy i umiejętność radzenia sobie ze związanymi z nią problemami. Przykładowa pozycja tej dymensji brzmi: Czuję, że mam pozytywny wpływ na życie innych. Osoby wypełniające kwestionariusz są proszone o ustosunkowanie się do jego kolejnych twierdzeń przez wykorzystanie siedmiostopniowej skali, pozwalającej na ocenę częstotliwości doświadczania poszczególnych symptomów.

Skala stresu nauczycielskiego (SSN). Narzędzie to zostało opracowane przez Tucholską (2009) na podstawie Inwentarza źródeł stresu nauczycielskiego autorstwa Boyle'a, Borga, Falzona i Baglioniego (1995). Polska wersja testu zawiera 20 oryginalnych i 10 eksperymentalnych pytań, na które badani odpowiadają, korzystając z pięciostopniowej skali odpowiedzi. Kwestionariusz umożliwia określenie poziomu odczuwanego stresu w sześciu aspektach związanych z pracą nauczyciela. $\mathrm{W}$ prezentowanych analizach uwzględniono tylko jeden wymiar stresu, który w badaniach okazuje się najsilniej korelować z każdą z dymensji wypalenia (Hreciński, 2016; Tucholska, 2009). Pozwala on na ocenę nasilenia stresu mającego swoje zasadnicze źródło w niezdyscyplinowaniu i braku uprzejmości uczniów, prowadzeniu zajęć w zbyt licznych klasach, braku czasu na odpoczynek między lekcjami oraz poczuciu przeciążenia z powodu przygotowywania lekcji, oceniania prac uczniów itp. Skala składa się z siedmiu itemów ( $\alpha$ Cronbacha $=0,77$ ). Przykładowe pytanie tego wymiaru brzmi: Jak dużym źródtem stresu jest dla Ciebie trudna klasa?

Skala religijnego radzenia sobie (Brief $\mathrm{RCOPE}$ ). Zastosowane $\mathrm{w}$ tych badaniach narzędzie zostało opracowane przez Jarosza (2011) i stanowi adaptację krótszej wersji popularnego kwestionariusza Brief RCOPE, skonstruowanego przez Pargamenta, Smitha, Koeniga i Perez (1998). Podobnie jak wersja oryginalna, składa się on z 14 pozycji testowych i pozwala na ocenę pozytywnych oraz negatywnych religijnych strategii zaradczych. Skala PRC (siedem itemów; a Cronbacha $=0,86$ ) pozwala określić stosowane $\mathrm{w}$ stresie odniesienia do religii, które umożliwiają konstruktywne radzenie sobie z trudnościami. Przykładowa pozycja należąca do tego wymiaru brzmi: Próbowałem dostrzec, jak 
Bóg może próbować wzmocnić mnie w tej sytuacji. Skala NRC (siedem itemów; a Cronbacha $=0,74$ ) określa podejmowane $\mathrm{w}$ stresie odniesienia do religii, które nie sprzyjają konstruktywnemu radzeniu sobie z doświadczanymi trudnościami. Przykładowa pozycja tego wymiaru brzmi: Zastanawiałem się, co uczyniłem, że Bóg mnie ukarat. Wersja narzędzia opracowana przez Jarosza (2011) zawiera pięciostopniową skalę odpowiedzi.

Arkusz personalny. Za pomocą arkusza zebrano dane o płci badanych, ich wieku, stanie cywilnym, statusie kościelnym oraz miejscu pracy.

\section{WYNIKI}

Statystyki opisowe badanych zmiennych zostały przedstawione w tabeli 1 . Sporządzono je na bazie wyników surowych. Ponieważ twierdzenia skali do pomiaru obniżonego poczucia osiągnięć są sformułowane w sposób pozytywny, czyli odmiennie niż w wypadku dwóch pozostałych wymiarów wypalenia, dla ułatwienia interpretacji odwrócono wyniki w tej dymensji. Wysokie wyniki prezentowane w analizach dla tej skali oznaczają zatem nasilone poczucie braku osiągnięć w pracy.

Wyliczone dla zastosowanych skal współczynniki a Cronbacha wskazują, że pomiar badanych zmiennych w grupie nauczycieli religii miał satysfakcjonujący poziom rzetelności wewnętrznej. Najniższy poziom zgodności wewnętrznej uzyskano dla skali depersonalizacji. Jest on jednak zadowalający i nie odbiega od oryginalnej wersji testu.

Tabela 1

Średnie, odchylenia standardowe, wspótczynniki zgodności wewnętrznej oraz interkorelacje $r$-Pearsona badanych zmiennych $(N=419)$

\begin{tabular}{lrrrrrrrc}
\hline \multicolumn{1}{c}{ Zmienna } & \multicolumn{1}{c}{$M$} & \multicolumn{1}{c}{$S D$} & $\alpha$ & 1 & 2 & 3 & 4 & 5 \\
\hline 1. Stres & 2,05 & 0,69 & 0,82 & & & & & \\
2. PRC & 27,84 & 3,86 & 0,79 & $-0,03$ & & & & \\
3. NRC & 13,27 & 3,98 & 0,80 & $0,33^{*}$ & $-0,06$ & & & \\
4. EW & 20,46 & 8,06 & 0,85 & $0,58^{*}$ & $-0,10$ & $0,26^{*}$ & & \\
5. DP & 5,90 & 3,67 & 0,70 & $0,38^{*}$ & $-0,13^{*}$ & $0,24^{*}$ & $0,54^{*}$ & \\
6. BPO & 14,40 & 5,46 & 0,84 & $0,36^{*}$ & $-0,26^{*}$ & $0,17^{*}$ & $0,48^{*}$ & $0,54^{*}$ \\
\hline
\end{tabular}

Adnotacja. PRC - pozytywne religijne radzenie sobie; NRC - negatywne religijne radzenie sobie; EW - emocjonalne wyczerpanie; DP - depersonalizacja; BPO - brak poczucia osiągnięć.

${ }^{*} p<0,001$.

W tabeli 1 przedstawiono również interkorelacje między zmiennymi. Stres odczuwany przez nauczycieli istotnie koreluje z wymiarami wypalenia zawodowego, przy czym najsilniej jest on powiązany $\mathrm{z}$ emocjonalnym wyczerpaniem $(r=0,58)$. Ponadto koreluje tylko z jednym rodzajem strategii zaradczych - NRC. 
W przypadku tej strategii stwierdzono też, że jest ona dodatnio powiązana ze wszystkimi wymiarami wypalenia. PRC korelują natomiast ujemnie z ujawnianymi przez katechetów symptomami wypalenia.

Moderacyjna rola PRC $w$ relacji między stresem a wypaleniem zawodowym nauczycieli została sprawdzona za pomocą analizy regresji. W tym celu zmienną stresu oraz PRC poddano zabiegowi centracji metodą standaryzacji wyników każdej z tych zmiennych. Następnie, mnożąc przez siebie obie wystandaryzowane zmienne, utworzono składnik interakcyjny. Wykonując hierarchiczną analizę regresji dla każdego z wymiarów wypalenia zawodowego, do pierwszego modelu wprowadzono zmienne stresu i PRC, w drugim zaś dodano do nich składnik interakcyjny (patrz tabela 2).

Tabela 2

Wyniki analiz regresji dla badanych zmiennych $z$ uwzględnieniem interakcji stresu i pozytywnego radzenia sobie $(N=419)$

\begin{tabular}{|c|c|c|c|c|c|c|c|c|c|c|}
\hline \multirow{2}{*}{$\begin{array}{c}\text { Zmienna } \\
\text { wyjaśniana }\end{array}$} & \multirow{2}{*}{ Model } & \multirow{2}{*}{$\begin{array}{c}\text { Zmienne } \\
\text { wyjaśniające }\end{array}$} & \multirow{2}{*}{ Beta } & \multirow{2}{*}{$R^{2}$} & \multirow{2}{*}{$\begin{array}{c}\text { Skoryg. } \\
R^{2}\end{array}$} & \multicolumn{5}{|c|}{ Statystyki zmiany } \\
\hline & & & & & & $R^{2}$ & $F$ & $d f_{1}$ & $d f_{2}$ & $p$ \\
\hline \multirow[t]{5}{*}{ EW } & 1 & Stres & $0,57 * * *$ & & & & & & & \\
\hline & & PRC & $-0,08$ & 0,34 & 0,33 & 0,34 & 105,42 & 2 & 416 & $<0,001$ \\
\hline & 2 & Stres & $0,58^{* * *}$ & & & & & & & \\
\hline & & PRC & $-0,08^{*}$ & & & & & & & \\
\hline & & Stres $\times$ PRC & $-0,11^{* *}$ & 0,35 & 0,34 & 0,01 & 7,31 & 1 & 415 & 0,007 \\
\hline \multirow[t]{5}{*}{ DP } & 1 & Stres & $0,38 * * *$ & & & & & & & \\
\hline & & PRC & $-0,12 * *$ & 0,16 & 0,16 & 0,16 & 39,30 & 2 & 416 & $<0,001$ \\
\hline & 2 & Stres & $0,38 * * *$ & & & & & & & \\
\hline & & PRC & $-0,12^{* *}$ & & & & & & & \\
\hline & & Stres $\times$ PRC & $-0,10^{*}$ & 0,17 & 0,16 & 0,01 & 4,14 & 1 & 415 & 0,043 \\
\hline \multirow[t]{5}{*}{ BPO } & 1 & Stres & $0,36 * * *$ & & & & & & & \\
\hline & & PRC & $-0,25 * * *$ & 0,19 & 0,19 & 0,19 & 49,55 & 2 & 416 & $<0,001$ \\
\hline & 2 & Stres & $0,37 * * *$ & & & & & & & \\
\hline & & PRC & $-0,25 * * *$ & & & & & & & \\
\hline & & Stres $\times$ PRC & $-0,14^{* *}$ & 0,21 & 0,21 & 0,02 & 10,03 & 1 & 415 & 0,002 \\
\hline
\end{tabular}

Adnotacja. EW - emocjonalne wyczerpanie; DP - depersonalizacja; BPO - brak poczucia osiągnięć; PRC - pozytywne religijne radzenie sobie.

${ }^{\star} p<0,05 ;{ }^{* *} p<0,01 ;{ }^{* *} p<0,001$.

Model wyjaśniający wariancję wyczerpania emocjonalnego z uwzględnieniem składnika interakcyjnego okazał się dobrze dopasowany do danych $(F=$ 7,$\left.31 ; d f_{1}=1 ; d f_{2}=415 ; p<0,01\right)$. Istotne statystycznie okazały się także wyniki analiz regresji z interakcją stresu i PRC, wyjaśniające zmienność wyników depersonalizacji $\left(F=4,14 ; d f_{1}=1 ; d f_{2}=415 ; p<0,05\right)$ i braku poczucia osiągnięć $\left(F=10,03 ; d f_{1}=1 ; d f_{2}=415 ; p<0,01\right)$. Niemniej jednak wprowadzenie do modelu 
regresyjnego składnika interakcyjnego poprawiało procent wyjaśnianej wariancji poszczególnych wymiarów wypalenia zaledwie o 1-2\%.

Aby dokonać charakterystyki występującej interakcji, dokonano podziału danych na zbiory o wysokich i niskich wynikach w skali PRC. Posłużono się przy tym odchyleniem ćwiartkowym. Wyodrębniono więc grupę $25,5 \%$ badanych $(n=107)$, którzy uzyskali najwyższe wskaźniki PRC, i grupę 25,3\% osób $(n=106)$, które uzyskały najniższe wyniki w tej skali. Kolejny etap obliczeń polegał na wykonaniu analiz regresji, w których zmienną wyjaśnianą była określona dymensja wypalenia, a zmienną wyjaśniającą - poziom stresu odczuwanego przez nauczycieli. Każda analiza była wykonywana osobno dla wyodrębnionych wcześniej grup osób o wysokich i niskich wynikach w skali PRC. Uzyskane modele regresji okazały się dobrze dopasowane do danych $(p<0,01)$. Na rysunku 1 przedstawiono uproszczone wykresy ilustrujące współzależność między stresem a poszczególnymi dymensjami wypalenia przy różnym nasileniu PRC. Ich analiza wskazuje, że siła związku między stresem a poszczególnymi wymiarami wypalenia zawodowego zmienia się w zależności od stosowania PRC. Jest ona mniejsza, gdy nasilenie strategii zaradczych jest większe. Spośród trzech wymiarów wypalenia moderacyjna rola PRC jest najbardziej wyraźna w odniesieniu do zmiennej brak poczucia osiągnięć w pracy nauczyciela.

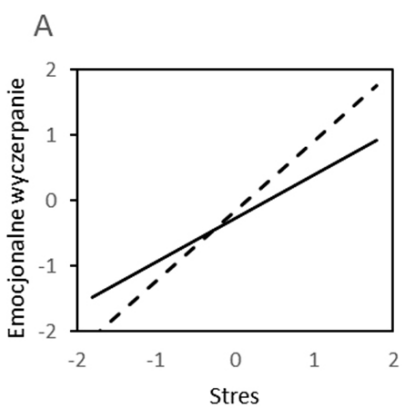

Pozytywne radzenie sobie wysokie nasilenie niskie nasilenie

Wartości zmiennych wyrażono w jednostkach standaryzowanych
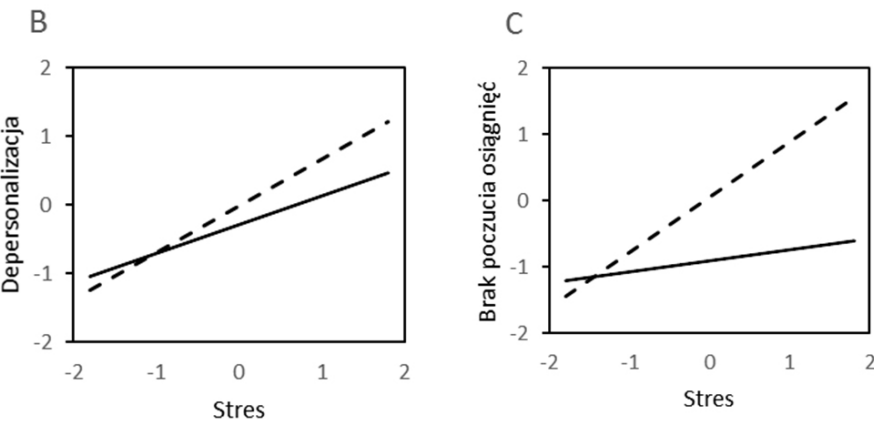

Rysunek 1.

Linie regresji obrazujące związek między stresem a emocjonalnym wyczerpaniem (A), depersonalizacją (B), brakiem poczucia osiągnięć (C) przy wysokim i niskim nasileniu pozytywnego religijnego radzenia sobie. 


\section{Podsumowanie I DYSKUSJA}

Przeprowadzone badania dowodzą istnienia zróżnicowanych współzależności między religijnymi sposobami radzenia sobie a odczuwanym stresem i wypaleniem zawodowym. Strategie zaradcze określane jako pozytywne okazały się korelować ujemnie z depersonalizacją na poziomie bardzo niskim oraz $\mathrm{z}$ brakiem poczucia osiągnięć $\mathrm{w}$ pracy na poziomie niskim. Związek z wyczerpaniem emocjonalnym, choć ujemny, nie osiągnął wymaganej istotności statystycznej. Kierunek współzależności między badanymi zmiennymi okazał się tym samym zgodny z H1. Nie potwierdziła się jednak postulowana negatywna korelacja PRC ze stresem. Wyniki analiz potwierdziły sformułowany w $\mathrm{H} 2$ kierunek powiązań między NRC a poszczególnymi wymiarami wypalenia. $\mathrm{W}$ tym przypadku religijne radzenie sobie korelowało dodatnio $\mathrm{z}$ wyczerpaniem emocjonalnym i depersonalizacją na poziomie niskiej siły związku, z brakiem poczucia osiągnięć natomiast - na poziomie bardzo niskim. Przeprowadzone analizy potwierdziły także postulowaną w $\mathrm{H} 3$ moderacyjną rolę $\mathrm{PRC} w$ relacji między stresem a wypaleniem zawodowym.

Uzyskane wyniki badań korespondują z ustaleniami innych autorów, wskazujących na różnoraki charakter poszczególnych strategii zaradczych. NRC ujawniały następujące bezpośrednie powiązania: $\mathrm{z}$ doświadczanymi trudnościami i odczuwanym stresem (Da Silva, Dillon, Verdejo, Sanchez, De La Rosa, 2017), ze stopniem przystosowania się do stresujących sytuacji (Terreri, Glenwick, 2013) oraz z objawami niepokoju i depresji (Carpenter, Laney, Mezulis, 2012; Ramirez i in., 2012; Ahles, Mezulis, Hudson, 2016). Na podstawie badań poprzecznych i podłużnych przeprowadzonych w różnych próbach stwierdzono, że osoby stosujące NRC odczuwają więcej stresu, trudniej im się do niego przystosować i częściej doświadczają jego następstw (Ano, Vasconcelles, 2005). Jako konsekwencję przedłużającego się stresu, tym razem związanego z pracą, uważa się także wypalenie zawodowe. Prezentowane badania własne potwierdzają słuszność tego podejścia. NRC korelują bowiem dodatnio z poszczególnymi wymiarami wypalenia tym silniej, im bardziej są one powiązane ze stresem, czyli głównie z wyczerpaniem emocjonalnym i depersonalizacją, a w dalszej kolejności z obniżonym przekonaniem o własnej skuteczności.

Korelacyjny charakter badań nie pozwala na jednoznaczne wyjaśnienie związku między NRC a stresem i jego konsekwencjami. Zdaniem Ano i Vasconcellesa (2005) charakterystyczne dla tego rodzaju strategii: poczucie bycia ukaranym lub odrzuconym przez Boga, kwestionowanie Bożej mocy, przypisywanie odpowiedzialności za problemy demonowi lub wyrażanie niezadowolenia wobec członków wspólnoty religijnej mogą wywoływać odpowiednio: poczucie winy, przygnębienie i samotność, bezradność, niepokój i lęk oraz prowadzić do izolacji. Tym samym osoba stosująca takie sposoby radzenia sobie naraża się na większy stres i uniemożliwia korzystanie z zasobów pozwalających na rozwiązanie lub choćby zmniejszenie doświadczanych trudności. 
Z drugiej strony sięganie po NRC może odpowiadać dyspozycjom stosujących je osób: pasywności, przerzucaniu odpowiedzialności na innych, samoobwinianiu i utrzymywaniu negatywnego obrazu siebie. Należy również wziąć pod uwagę, że NRC mogą być uruchamiane wtedy, gdy poziom doświadczanych przez jednostkę trudności jest tak duży, że przekracza zasoby, które były wystarczające $\mathrm{w}$ zmaganiu się z codziennymi problemami.

Zaobserwowany brak związku między stresem odczuwanym przez nauczycieli religii a stosowaniem przez nich PRC okazuje się zbieżny z wynikami innych autorów, szukających relacji między tym rodzajem strategii zaradczych a stresem doświadczanym przez: duchownych (Horton, 2006), adolescentów (Terreri, Glenwick, 2013) czy dorosłych imigrantów (Da Silva i in., 2017). Na podstawie przeprowadzonej metaanalizy Ano i Vasconcelles (2005) zauważyli, że związek PRC ze stresem jest dostrzegalny dopiero w dłuższej perspektywie czasowej; istnieją jednak badania, w których nie udało się takiego związku potwierdzić (Horton, 2006; Maldonado Feliciano, 2005). Rezultaty badań mogą zatem sugerować, że pozytywne odwołanie do religii w trudnościach chroni nie tyle przed odczuwaniem samego stresu, ile przed jego odległymi następstwami. Uzyskane negatywne korelacje między PRC a poszczególnymi wymiarami wypalenia u nauczycieli religii wydają się wpisywać w taki obraz współzależności. Ponadto PRC, w porównaniu z pozostałymi dymensjami wypalenia, najsilniej korelują z brakiem poczucia osiągnięć osobistych i w odniesieniu do tej zmiennej wykazują największy efekt moderacji. Brak poczucia osiągnięć różni się zaś od pozostałych dymensji wypalenia m.in. tym, że ujawnia słabsze od nich powiązanie ze stresem i jest uważany za bardziej odległy w czasie skutek obciążeń (Demerouti i in., 2001; Maslach, 2010; Sęk, 1994). Warto zaznaczyć, że najsilniejsze powiązanie PRC z poczuciem braku osiągnięć osobistych koresponduje także $\mathrm{z}$ analogicznym wzorcem powiązań między poszczególnymi wymiarami wypalenia a tzw. ogólnymi strategiami radzenia sobie ukierunkowanymi na problem (Hreciński, 2016). Taki obraz współzależności w pewnej mierze potwierdzają wyniki badań przeprowadzonych przez Terreriego i Glenwicka (2013), którzy ustalili, że PRC korelują z ogólnymi sposobami radzenia zorientowanymi na problem oraz ze strategią poszukiwania wsparcia społecznego. Strategie odwołujące się do religii różnią się jednak od ogólnych sposobów radzenia sobie tym, że PRC nie korelują ze stresem. Zdaniem niektórych PRC mogą wchodzić w interakcję z innymi czynnikami, takimi jak: optymizm, pesymizm, poczucie własnej wartości (Knabb, Grigorian-Routon, 2014; Kvande, Klöckner, Moksnes, Espnes, 2015). Ze względu na takie powiązania PRC mogłyby ujawniać brak bezpośrednich korelacji ze stresem, ale zarazem pełnić funkcję wspomagającą w ochronie przed jego niepożądanymi następstwami.

Choć badania empiryczne nie dostarczają materiału pozwalającego na dokładne i jednoznaczne wyjaśnienie sposobu, w jaki PRC chronią przed skutkami stresu, to potwierdzają, że w porównaniu do ogólnych metod radzenia sobie 
strategie religijne wnoszą unikatowy wkład w przystosowanie jednostki do doświadczanych problemów (Pargament, 1997; Terreri, Glenwick, 2013). W świetle rezultatów badań własnych PRC mogą być słusznie uważane za jeden z zasobów katechetów, który - zgodnie z założeniami modelu JD-R - stanowi rodzaj buforu przed symptomami wypalenia zawodowego, rozwijanego w następstwie stresu doświadczanego w pracy. Związek NRC ze stresem oraz większym nasileniem wypalenia zawodowego, szczególnie emocjonalnym wyczerpaniem i depersonalizacją, potwierdza natomiast zasadność traktowania tego rodzaju strategii jako nieefektywnych sposobów radzenia sobie z trudną sytuacją. Ustalenia te pociągają za sobą pewne implikacje praktyczne. Planując oddziaływania mające na celu wzmacnianie kompetencji zawodowych nauczycieli religii, warto zwracać ich uwagę na występowanie pozytywnych i negatywnych odwołań do religii w trudnościach i związanych z tym konsekwencji. Dla osób odpowiedzialnych za wspieranie pracy katechetów identyfikacja rodzaju stosowanych przez nich sposobów religijnego radzenia sobie może ponadto stanowić pomoc w rozpoznawaniu skali przeżywanych przez pracowników trudności. Nasilone korzystanie z NRC może bowiem świadczyć o pojawieniu się dużych obciążeń w pracy oraz o braku wystarczających kompetencji zawodowych lub dyspozycji osobowych, aby się do nich przystosować. Może też wskazywać na przeżywany przez nauczyciela kryzys. Stosowanie NRC może być zatem sygnałem, że osoba potrzebuje pomocy (García, Páez, Reyes-Reyes, Álvarez, 2017; Pargament i in., 1998; Pargament i in., 2011).

Choć prezentowane badania zostały przeprowadzone wśród nauczycieli religii, to można przypuszczać, że przedstawione powiązania zmiennych odnoszą się także do nauczycieli innych przedmiotów, pod warunkiem że religia stanowi $\mathrm{w}$ ich życiu istotny punkt odniesienia. Dołączanie problematyki religijnego radzenia sobie do oferowanych nauczycielom tzw. warsztatów radzenia sobie może poszerzyć repertuar stosowanych przez nich strategii zaradczych oraz pomóc $\mathrm{w}$ rozumieniu roli, jaką odgrywają $\mathrm{w}$ tym procesie.

Chociaż prezentowane badania wskazują, że PRC wiążą się z mniejszym natężeniem symptomów wypalenia, to siła tego związku jest niewielka. Oznacza to, że szukanie wsparcia w religii w sytuacji doświadczanych trudności zawodowych nie gwarantuje dużej ochrony przed ryzykiem wypalenia. Należy jednak zaznaczyć, że niskie współzależności między zjawiskiem wypalenia a radzeniem sobie ze stresem dotyczą także tych strategii zaradczych, które nie odwołują się do religii (Grzegorzewska, 2006; Hreciński, 2016; Ogińska-Bulik, 2006; Ogińska-Bulik, Kaflik-Pieróg, 2006; Wallace, Lee, Lee, 2010).

Przeprowadzone badania nie obejmowały pomiaru typu religijności i stopnia religijnego zaangażowania respondentów. Zmienne te wykazują duży związek z tym, jakiego rodzaju religijne strategie są przez osobę preferowane oraz $\mathrm{w}$ jakim stopniu korzystanie $\mathrm{z}$ nich chroni przed negatywnymi następstwami stresu albo im sprzyja (Knabb, Grigorian-Routon, 2014; Krok, 2015; Pargament 
i in., 1992). Uwzględnienie ich w przyszłych badaniach może pomóc w lepszym zrozumieniu związków między odniesieniem do religii w sytuacji stresu a wypaleniem zawodowym.

\section{Bibliografia}

Ahles, J. J., Mezulis, A. H., Hudson, M. R. (2016). Religious coping as a moderator of the relationship between stress and depressive symptoms. Psychology of Religion and Spirituality, 8, 228-234. DOI:10.1037/rel0000039

Ano, G. G., Vasconcelles, E. B. (2005). Religious coping and psychological adjustment to stress: A meta-analysis. Journal of Clinical Psychology, 61, 461-480. DOI:10.1002/jclp.20049

Bakker, A. B., Demerouti, E. (2007). The job demands-resources model: State of the art. Journal of Managerial Psychology, 22, 309-328. DOI:10.1108/02683940710733115

Bakker, A. B., Demerouti, E., Euwema, M. C. (2005). Job resources buffer the impact of job demands on burnout. Journal of Occupational Health Psychology, 10, 170-180. DOI:10.1037/1076-8998.10.2.170

Bakker, A. B., Hakanen, J. J., Demerouti, E. (2007). Job resources boost work engagement, particularly when job demands are high. Journal of Educational Psychology, 99, 274-284. DOI:10.1037/0022-0663.99.2.274

Bartczuk, R., Jarosz, M. (2006). Funkcja religijności w procesie radzenia sobie ze stresem. Koncepcja Kennetha I. Pargamenta. Roczniki Psychologiczne, 9, 37-52.

Boyle, G. J., Borg, M. G., Falzon, J. M., Baglioni, J. A. (1995). A structural model of the dimensions of teacher stress. British Journal of Educational Psychology, 65, 49-67. DOI:10.1111/j.2044-8279.1995.tb01130.x

Burke, R. J., Greenglass, E. R., Schwarzer, R. (1996). Predicting teacher burnout over time: Effects of work stress, social support, and self-doubts on burnout and its consequences. Anxiety, Stress \& Coping: An International Journal, 9, 261-275. DOI:10.1080/10615809608249406

Carpenter, T. P., Laney, T., Mezulis, A. (2012). Religious coping, stress, and depressive symptoms among adolescents: A prospective study. Psychology of Religion and Spirituality, 4, 19-30. DOI:10.1037/a0023155

Chirico, F. (2017). Religious belief and mental health in lay and consecrated Italian teachers, Journal of Religion and Health, 56(3), 839-851. DOI:10.1007/ s10943-016-0242-7

Da Silva, N., Dillon, F. R., Verdejo, T. R., Sanchez, M., De La Rosa, M. (2017). Acculturative stress, psychological distress, and religious coping among Latina young adult immigrants. The Counseling Psychologist, 45, 213-236. DOI:10.1177/0011000017692111 
Demerouti, E., Bakker, A. B. (2011). The job demands-resources model: Challenges for future research. South African Journal of Industrial Psychology, 37(2), 1-9. DOI:10.4102/sajip.v37i2.974

Demerouti, E., Bakker, A. B., Nachreiner, F., Schaufeli, W. B. (2001). The job demands-resources model of burnout. Journal of Applied Psychology, 86, 499-512. DOI:10.1037/0021-9010.86.3.499

García, F. E., Páez, D., Reyes-Reyes, A., Álvarez, R. (2017). Religious coping as moderator of psychological responses to stressful events: A longitudinal study. Religions, 8(4), 62. DOI:10.3390/rel8040062

Grzegorzewska, M. K. (2006). Stres w zawodzie nauczyciela. Specyfika, uwarunkowania i następstwa. Kraków: Wyd. UJ.

Heszen-Niejodek, I. (2000). Teoria stresu psychologicznego i radzenia sobie. W: J. Strelau (red.), Psychologia. Podręcznik akademicki (t. 3, s. 465-492). Gdańsk: GWP.

Horton, K. D. (2006). Effects of job stress, religious coping, and social support on clergy mental health: Longitudinal evidence from a national sample of Presbyterian clergy. Praca magisterska. University of Texas at Austin. Pobrane z: https://repositories.lib.utexas.edu/handle/2152/30157

Hreciński, P. (2016). Wypalenie zawodowe nauczycieli. Warszawa: Difin.

Jarosz, M. (2011). Skala religijnego radzenia sobie - wersja skrócona (Brief RCOPE). W: M. Jarosz (red.), Psychologiczny pomiar religijności (s. 293-316). Lublin: TN KUL.

Knabb, J. J., Grigorian-Routon, A. (2014). The role of experiential avoidance in the relationship between faith maturity, religious coping, and psychological adjustment among Christian university students. Mental Health, Religion \& Culture, 17, 458-469. DOI:10.1080/13674676.2013.846310

Krok, D. (2015). Value systems and religiosity as predictors of nonreligious and religious coping with stress in early adulthood. Archives of Psychiatry and Psychotherapy, 17(3), 21-31. DOI:10.12740/APP/59050

Kvande, M. N., Klöckner, C. A., Moksnes, U. K., Espnes, G. A. (2015). Do optimism and pessimism mediate the relationship between religious coping and existential well-being? Examining mechanisms in a Norwegian population sample. The International Journal for the Psychology of Religion, 25, 130-151. DOI:10.1080/10508619.2014.892350

LaBarbera, R., Hetzel, J. (2016). Christian educators' use of prayer to cope with stress. Journal of Religion and Health, 55, 1433-1448. DOI:10.1007/ s10943-015-0118-2

Maldonado Feliciano, L. E. (2005). Coping, social support, biculturalism, and religious coping as moderators of the relationship between occupational stress and depressive affect among Hispanic psychologists. Rozprawa doktorska. Maryland: University of Maryland. Pobrane z: http://drum.lib.umd.edu/ handle/1903/2913 
Maslach, C. (1982). Understanding burnout: Definitional issues in analyzing a complex phenomenon. W: W. S. Paine (red.), Job stress and burnout (s. 29-40). Beverly Hills, CA: Sage.

Maslach, C. (1998). A multidimensional theory of burnout. W: C. L. Cooper (red.), Theories of organizational stress (s. 68-85). Nowy Jork: Oxford University Press.

Maslach, C. (2010). Wypalenie - w perspektywie wielowymiarowej. W: H. Sęk (red.), Wypalenie zawodowe. Przyczyny i zapobieganie (s. 13-31). Warszawa: PWN.

Maslach, C., Jackson, S. E. (1981). The measurement of experienced burnout. Journal of Occupational Behavior, 2, 99-113. DOI:10.1002/job.4030020205

Maslach, C., Leiter, M. (2011). Prawda o wypaleniu zawodowym. Co robić ze stresem $w$ organizacji. Warszawa: PWN.

Maslach, C., Schaufeli, W. B., Leiter, M. P. (2001). Job burnout. Annual Review of Psychology, 52, 397-422. DOI:10.1146/annurev.psych.52.1.397

Noh, H., Chang, E., Jang, Y., Lee, J. H., Lee, S. M. (2016). Suppressor effects of positive and negative religious coping on academic burnout among Korean middle school students. Journal of Religion and Health, 55, 135-146. DOI:10.1007/s10943-015-0007-8

Ogińska-Bulik, N. (2006). Stres zawodowy w zawodach usług społecznych. Źródła, konsekwencje, zapobieganie. Warszawa: Difin.

Ogińska-Bulik, N., Kaflik-Pieróg, M. (2006). Stres zawodowy w służbach ratowniczych. Łódź: Wyd. Wyższej Szkoły Humanistyczno-Ekonomicznej w Łodzi.

Pargament, K. I. (1997). The psychology of religion and coping. Theory, research, practice. Nowy Jork: Guilford Press.

Pargament, K. I., Feuille, M., Burdzy, D. (2011). The Brief RCOPE: Current psychometric status of a short measure of religious coping, Religions, 2(4), 51-76. DOI:10.3390/rel2010051

Pargament, K. I., Olsen, H., Reilly, B., Falgout, K., Ensing, D. S., van Haitsma, K. (1992). God help me (II): The relationship of religious orientations to religious coping with negative life events. Journal for the Scientific Study of Religion, 31, 504-513. DOI:10.2307/1386859

Pargament, K. I., Smith, B. W., Koenig, H. G., Perez, L. (1998). Patterns of positive and negative religious coping with major life stressors. Journal for the Scientific Study of Religion, 37, 710-724. DOI:10.2307/1388152

Ramirez, S. P., Macêdo, D. S., Sales, P. M. G., Figueiredo, S. M., Daher, E. F., Araújo, S. M., ... Carvalho, A. F. (2012). The relationship between religious coping, psychological distress and quality of life in hemodialysis patients. Journal of Psychosomatic Research, 72, 129-135. DOI:10.1016/j.jpsychores.2011.11.012

Sęk, H. (1994). Wypalenie zawodowe u nauczycieli. Społeczne i podmiotowe uwarunkowania. W: J. Brzeziński, L. Witkowski (red.), Edukacja wobec zmiany społecznej (s. 325-343). Poznań-Toruń: Edytor. 
Terreri, C. J., Glenwick, D. S. (2013). The relationship of religious and general coping to psychological adjustment and distress in urban adolescents. Journal of Religion and Health, 52, 1188-1202. DOI:10.1007/s10943-011-9555-8

Tucholska, S. (2009). Wypalenie zawodowe u nauczycieli. Psychologiczna analiza zjawiska i jego osobowościowych uwarunkowań. Lublin: Wyd. KUL.

Wallace, S. L., Lee, J., Lee, S. M. (2010). Job stress, coping strategies, and burnout among abuse-specific counselors. Journal of Employment Counseling, 47, 111-122. DOI:10.1002/j.2161-1920.2010.tb00096.x

Xanthopoulou, D., Bakker, A. B., Demerouti, E., Schaufeli, W. B. (2007). The role of personal resources in the job demands-resources model. International Journal of Stress Management, 14, 121-141. DOI:10.1037/1072-5245.14.2.121

Xanthopoulou, D., Bakker, A. B., Dollard, M. F., Demerouti, E., Schaufeli, W. B., Taris, T. W., Schreurs, P. G. (2007). When do job demands particularly predict burnout? The moderating role of job resources. Journal of Managerial Psychology, 22, 766-786. DOI:10.1108/02683940710837714 